\title{
Optimization of Raw Material Composition in an Agricultural Biogas Plant
}

\author{
Lili Mézes ${ }^{1}$, Attila Bai ${ }^{2, *}$, Dávid Nagy², István Cinka², Zoltán Gabnai ${ }^{2}$ \\ 1: Institute of Water- and Environmental Management, Faculty of Agricultural and Food Sciences and \\ Environmental Management, University of Debrecen, Debrecen, Hungary \\ 2: Department of Business Economics, Institute of Applied Economics, Faculty of Economics and Business, \\ University of Debrecen, Debrecen, Hungary
}

Received November 3, 2016; Accepted December 1, 2016; Published January 1, 2017

\begin{abstract}
We analyzed the operation of a typical agricultural biogas plant in Hungary. Our aim was to optimize the composition of substrates for the biogas production and make a correct recommendation for completing feedstock recipes by considering the raw materials and technologies analyzed. The calculations were based on a very detailed database (including the daily operating data of 1673 days). Distribution of the biogas yields in summer and winter periods was normal based on the One-Sample Kolmogorov-Smirnov test, while the variance of data was homogeneous based on the Levene-test. Factor analysis of the biogas yield was performed with the Kaiser-Meyer-Olkin Measure of Sampling Adequacy probe (0.616) and the Bartlett's Test. According to the objectivity of our LP (linear program) model, we believe that a significant excess biogas yield (18-66\%) could be achieved by the use of our model compared to the actual measured data. Although the amount of corn silage, grass silage, and the extract - as variables - was minimal in the recipe, they played a crucial role in the total biogas yield of the recipe because of their significantly higher organic matter contents and specific biogas yields. Our results could provide a reliable foundation for optimizing of the recipe in biogas plants with raw material base similar to the analyzed plants.
\end{abstract}

Keywords: Biogas; Optimization; Heterosis Effect; Feedstock; Substrate

\section{Introduction}

Agriculture faces some major inter-connected challenges in delivering food security at a time of increasing pressures from population growth, changing consumption patterns and dietary preferences, and post-harvest losses. At the same time, there are growing opportunities and demands for the use of biomass to provide additional renewables, energy for heat, power and fuel, pharmaceuticals and green chemical feedstocks [1]. However, the worldwide potential of bioenergy is limited, because all land is multifunctional, and the land is also needed for food, feed, timber and fiber production, and for nature conservation and climate protection [2].

Fuchsz and Kohlheb (2015) [3] examined the environmental effects of anaerobic digestion (AD) plants, which operate with the same power production capacity, but use different raw materials during the full life circle. Their results showed that, from the perspective of greenhouse gas (GHG) emission, biogas production from energy crops 
cannot be regarded negatively, and having the lowest $\mathrm{CO}_{2}$ emissions $\left(\mathrm{CO}_{2}\right.$ absorber: -188 $\mathrm{g} / \mathrm{kWhe}$ ) of the three investigated AD plants. At the same time, energy-crop-only-based biogas production has the worst acidification potential because of the high fossil fuel demand in growing and transporting the raw materials. In addition, agricultural waste utilization for energy purposes is not always the best solution because of its high GHG emission; therefore, for environmental reasons, it is not always worth high-tech investment. The biogas plant that processes low-energy-density agricultural wastes produced $7.7 \%$ of its full-life-cycle $\mathrm{CO}_{2}$ emissions during its construction phase, compared with a $0.9 \%$ ratio for the biogas plant processing only energy crops. Interestingly, co-fermentation turned out to be the best option with regard to the energy efficiency, although its environmental consequences are moderate.

Present agricultural GHG reduction projects in Hungary cannot contribute to achieving long term GHG reduction goals to the same degree as that can be experienced in other sectors due to food market insecurities, food production limitations, and decreasing exchange quotation of GHG emissions. Consequently, climate-friendly agricultural investments have more advantageous returns than in other sectors [4].

The construction and operation of a biogas plant is a combination of economic and technical considerations [5]. Environmental conditions such as $\mathrm{pH}$, temperature, substrate type, total solid (TS) and volatile solid (VS) content of the substrate, hydraulic retention time (HRT), and acclimation periods, are the main factors affecting both the inhibition level in an anaerobic process under different total ammonium nitrogen (TAN) concentrations and the rate of biogas production [6].

Obtaining the maximum biogas yield, by fully digesting the biogas substrate, would require a long retention time of the substrate inside the digester and a correspondingly large digester size. It is thus important to ensure a stable and continuous supply of feedstock with suitable quality and quantities. Feedstock conditioning offers the significant potential for process optimization, and increases digestion rates and biogas yields [5]. Co-digestion of different materials may enhance the anaerobic digestion process due to better carbon and nutrient balances, and applying organic wastes also provides nutrients in excess [7].

The most used substrate in co-fermentation with biogas crops is pig or cow manure [8]. Grasses, including straws from wheat, rice, and sorghum, are a plentiful supply of biomass, most of which is produced as a waste product by food production [9]. Harvesting time can also significantly affect the composition of the substrate, and thus impact the biogas yield of plants $[10,11]$. Co-digestion of animal manure with various biomass substrates increases the biogas yield and offers a number of advantages for the management of manure and organic wastes [12] and for mitigation of greenhouse gas (GHG) emissions [13]. Wu et al. (2010) [14] concluded that significant increases in volumetric biogas production can be achieved by adding carbon rich agricultural residues to the co-digestion process with swine manure. Cuetos et al. (2008) [15] observed that co-digestion of mixtures stabilizes the feed to the bioreactor, thereby improving the $\mathrm{C} / \mathrm{N}$ ratio and decreasing the concentration of nitrogen. Cavinato et al. (2010) [16] studied the co-digestion of cattle manure, agricultural waste, and energy crops, where $1.10 \mathrm{l}$ /day biogas production rate and $1791 / \mathrm{kg}$ VS methane yield were detected and significant increase in biogas production from the co-digestion was observed. Other studies analyzed the methanogenesis processes during anaerobic digestion at different moisture levels (60$80 \%$ ), it has been reported that the highest methane production rates occurred at $60-80 \%$ of humidity [17] and [18]. An important parameter in determining the size of the biogas 
digester is the hydraulic retention time (HRT). The HRT is the average time interval when the substrate is kept inside the digester tank [5].

HRT is the average period that a given quantity of input material remains in the digester to be acted upon by the methanogens [19]. The disadvantage of a longer retention time is the increasing reactor size needed for a given amount of substrate to be treated [20]. A short HRT provides a good substrate flow rate, but a lower gas yield [5] and lower overall degradation [20]. Another problem for a short HRT is, that the bacteria in the digester are "washed out" faster than they can reproduce. It is therefore important to adapt the HRT to the specific decomposition rate of the used substrates. Knowing the targeted HRT, the daily feedstock input and the decomposition rate of the substrate, it is possible to calculate the necessary digester volume. The average HRT is usually varies from 20 to 40 days [5], under other results from 10 to 30 days [21], depending on the type of substrate and digestion temperature [5]. Kaosol and Sohgrathok (2012) [22] analyzed the effect of HRT on biogas production in a $15 \mathrm{~L}$ reactor with $10 \mathrm{~L}$ working volume for 10 days, 20 days, and 30 days. The results during the whole process showed that the 20day and 30-day HRT reactors can remove COD in the range of $92.28 \%-94.54 \%$, while the 10-day HRT reactor showed the lowest removal performance (i.e., 71.21\%). The COD removal performances of the 20-day HRT and the 30-day HRT reactors showed no significant difference.

In practice, the anaerobic degradation rate of organic matters from animal manure and slurries is about $40 \%$ for cattle slurry and of $65 \%$ for pig slurry, respectively. The degradation rate depends at large on the feedstock type, HRT, and process temperature. The organic load is an important operational parameter, which indicates how much organic dry matter can be fed into the digester per volume and time unit [5]).

Braun et al. (2006) [23] examined more than 40 agricultural biogas plants in his study. The plant sizes changed between $50 \mathrm{kWel}$ and $1672 \mathrm{kWel}$, the reactor volume varied between 1,000 and $17,000 \mathrm{~m}^{3}$. Therefore, the HRT changed significantly with the analyzed agricultural biogas plants. The organic load varied from 2.92 to $4.61 \mathrm{~m}^{3} / \mathrm{Vr} *$ day.

Menardo et al. (2011) [24] analyzed four mesophilic $\left(41^{\circ} \mathrm{C}\right)$ agricultural biogas plants. The digester volume changed between 4990 and $12000 \mathrm{~m}^{3}$, HRT varied from 51 to 105 days, while organic loading rate (OLR) was between 0.85 and $2.25 \mathrm{kgVs} / \mathrm{m}^{3 *}$ day.

The potential biogas yield relies not only on the VS content, but also on the degradability of those solids in an anaerobic environment [25]. Furthermore, both of these VS parameters depend on the OLR and HRT [26]. Menardo et al. (2011) [24] applied Pearson " $R$ " correlation coefficient analyses in his study and showed the parameters that were most correlated to the biogas yields of digestate samples were the OLR of the original biogas plant and the samples' TS and VS contents.

Many anaerobic digesters have various feedstock sources, which can cause fluctuations of the chemical composition in the reactor. As a result from poorly monitored systems, most anaerobic digesters are currently run at a less-than-optimum loading rate to prevent instability occurring in the digester. This instability often inhibits methanogens [27] and results in a decrease of the biogas yields.

Our hypothesis was that the quantity and quality of raw materials (dry or wet, organic material content, etc.) have an impact on the biogas and methane yields. We would like to prove the connection and correlation between the feedstock and the biogas yields, and to take into account the constraints often encountered in practice. We also analyzed the effect of seasonal differences on biogas yields. Our aim was to optimize the composition of substrates for biogas production and make a correct recommendation for 
completing feedstock recipes based on based on the raw materials and technologies analyzed.

Regarding the comparative analysis of actual and optimized feedstock recipes, our aim was to analyze the recipe's exact composition and biogas yield, based on the different feedstock quantities. We aimed to determine via linear program (LP) modelling (1) the recipes' potential reserves which can be suitable for yield-boosting effect and (2) the level of heterosis effect during co-fermentation compared to the biogas yield of single raw material.

\section{Materials and Methods}

The most important feature of the biogas plant studied between 2012-2016, is that it uses predominantly by-products generated in a nearby farm, providing a significant advantage for the feedstock management due to the predictable quantity and quality, and cost saving. Currently, the farm produces crops on 4,000 hectares of arable land including raw materials usable for biogas production (such as corn silage and grass silage). However, the main goal of the production is to provide food for the animal sector. The latter includes 2,000 dairy caws and almost 1,200 sows with progeny $(\sim 20,000$ piglets/year).

The raw material base for the mesophilic fermentation in the biogas plant is made up of various materials. The liquid part of the substrate consists of pig and cattle waste slurry, in addition to the whey and dairy sludge from the nearby cheese factory to be disposed in the biogas plant. The purpose of the biogas plant is the disposal of these continually generated unmarketable and environmentally dangerous products. In the remaining fermentation space of the fermenter - in order to enhance the biogas yield corn silage, grass silage, solid separated digestate, and manure are added, which have a significant dry matter content.

The majority of the raw materials fed daily consists of four liquid components: cattle slurry, pig slurry, whey, and sludge. The utilization of the total amount of these materials is especially important because of storage limits, and thus the limiting factors of their daily consumption must be taken into account during optimizing the process. Technical problems that were caused by the slurry happened a few times. The amount of incoming slurry had the significant fluctuations, causing either reduced amount fed in or (usually) higher proportion added.

Most biogas plants utilizing agricultural by-products use different recipes for the winter and summer periods, because the two-phase feeding of ruminants results in raw materials with different quality and quantity for each period. However, the plant analyzed in this study does not prevail this seasonality. According to its operating data, approximately $94 \%$ of the summer recipe and $92 \%$ of the winter recipe were composed of the four aforementioned liquid materials (Table 1.), resulting in balanced feeds and higher biogas yields compared to the changing recipes.

The raw materials were fed in the three mesophilic digesters of total $4,500 \mathrm{~m}^{3}$ capacity from the mixers between 2012 and 2016. The amount of material fed daily varied between 55.5 and $232.5 \mathrm{~m}^{3}$, and the average daily amount of feedstock substrate was $178 \mathrm{~m}^{3}$, which was equivalent to $18.8 \mathrm{t} /$ day. 
Table 1. Composition of feedstock-recipe for biogas production in summer and winter periods

\begin{tabular}{|l|c|c|}
\hline \multirow{2}{*}{ Used feedstocks } & Summer period & Winter period \\
\cline { 2 - 3 } & Average $( \pm$ SD) & Average ( \pm SD) \\
\hline Cattle slurry (\%) & $56.26 \pm 6.57$ & $51.76 \pm 12.01$ \\
\hline Pig slurry (\%) & $24.95 \pm 5.40$ & $27.71 \pm 8.37$ \\
\hline Silo maize (\%) & $1.92 \pm 1.33$ & $2.47 \pm 1.57$ \\
\hline Grass silage (\%) & $0.75 \pm 0.69$ & $0.95 \pm 0.85$ \\
\hline Solid separated digestate (\%) & $2.26 \pm 1.36$ & $2.33 \pm 1.16$ \\
\hline Whey (\%) & $6.48 \pm 2.74$ & $5.94 \pm 2.62$ \\
\hline Dairy sludge (\%) & $6.54 \pm 1.78$ & $6.35 \pm 2.24$ \\
\hline Cattle manure (\%) & $0.83 \pm 0.87$ & $0.47 \pm 0.73$ \\
\hline
\end{tabular}

SD: standard derivation

The average amount of biogas produced monthly was 171 thousand $\mathrm{Nm}^{3}$, while the daily biogas production varied between $3,638-7,265 \mathrm{Nm}^{3}$. The daily average of the produced biogas was $5,988.3 \mathrm{Nm}^{3}$, and the average methane yield was $3,310.8 \mathrm{Nm}^{3}$, from which electricity of $11,305.7 \mathrm{kWh} /$ day was generated in the biogas plant. The biogas production was calculated according to the gas flow meters of the digesters to figure out the overall daily gas yield in $\mathrm{Nm}^{3}$. The quality of biogas $\left(\mathrm{CH}_{4}, \mathrm{CO}_{2}, \mathrm{H}_{2} \mathrm{~S}, \mathrm{NH}_{4}\right)$ was analyzed with a ENVIRO-100 type gas analyzer. The average value of the methane concentration in biogas was $55 \%$, but the maximal value (76\%) indicated that a great potential is available, which can be achieved by a well-balanced, less various raw materials (Table 2.).

Table 2. Biogas quality parameters by the examined biogas plant

\begin{tabular}{|l|c|c|c|c|}
\hline \multicolumn{1}{|c|}{ Biogas quality } & $\mathbf{C H}_{\mathbf{4}}(\mathbf{\%})$ & $\mathbf{C O}_{2} \mathbf{( \% )}$ & $\left.\mathbf{H}_{\mathbf{2}} \mathbf{S} \mathbf{( m g} / \mathbf{k g}\right)$ & $\mathbf{O}_{\mathbf{2}} \mathbf{( \% )}$ \\
\hline Average $( \pm \mathrm{SD})$ & $55.16 \pm 4.82$ & $30.73 \pm 3.18$ & $123.04 \pm 122.18$ & $1.64 \pm 1.20$ \\
\hline Min. & 42.34 & 24.07 & 0.67 & 0.04 \\
\hline Max. & 75.69 & 53.08 & 699.50 & 8.98 \\
\hline
\end{tabular}

The average hydrogen-sulphide content of the biogas was $123 \mathrm{mg} / \mathrm{kg}$ after sulphur removal. The desulfurization was conducted with oxygen dozing, $\mathrm{FeCl}_{2}$ addiction, and biological processes. Preißler et al. (2010) [28] determined more rapid reduction of the $\mathrm{H}_{2} \mathrm{~S}$ content in the case of the iron (III) chloride variant. A $60 \%$ reduction of hydrogen sulphide content was achieved with the stoichiometric equal addition of iron in the case of the chlorides and the hydroxide compared with the control [28]. Based on the results, the combined sulphur-removal methods resulted in a very low $(200 \mathrm{mg} / \mathrm{kg}>)$ hydrogensulphide content in the produced biogas.

The daily organic load $\left(\mathrm{kg} / \mathrm{d}^{*} \mathrm{~m}^{3}\right)$ was calculated from the following equation: $\mathrm{OLR}=\mathrm{m} * \mathrm{c} / \operatorname{Vr}$ [5]. The average hydraulic retention time (HRT) was calculated from the maximal volume of the digesters $(\mathrm{Vr})\left(\mathrm{m}^{3}\right)$ and the amount of daily fed materials according to the following equation: $\mathrm{HRT}=\mathrm{Vr} / \mathrm{V}$, where $\mathrm{HRT}=$ hydraulic retention time [days], $\mathrm{Vr}=$ digester volume $\left[\mathrm{m}^{3}\right]$, and $\mathrm{V}=$ volume of substrate fed per time unit $\left[\mathrm{m}^{3} / \mathrm{d}\right]$ [19].

The operation of the plant from the biogas production point of view can be divided into three phases (Figure 1.). 


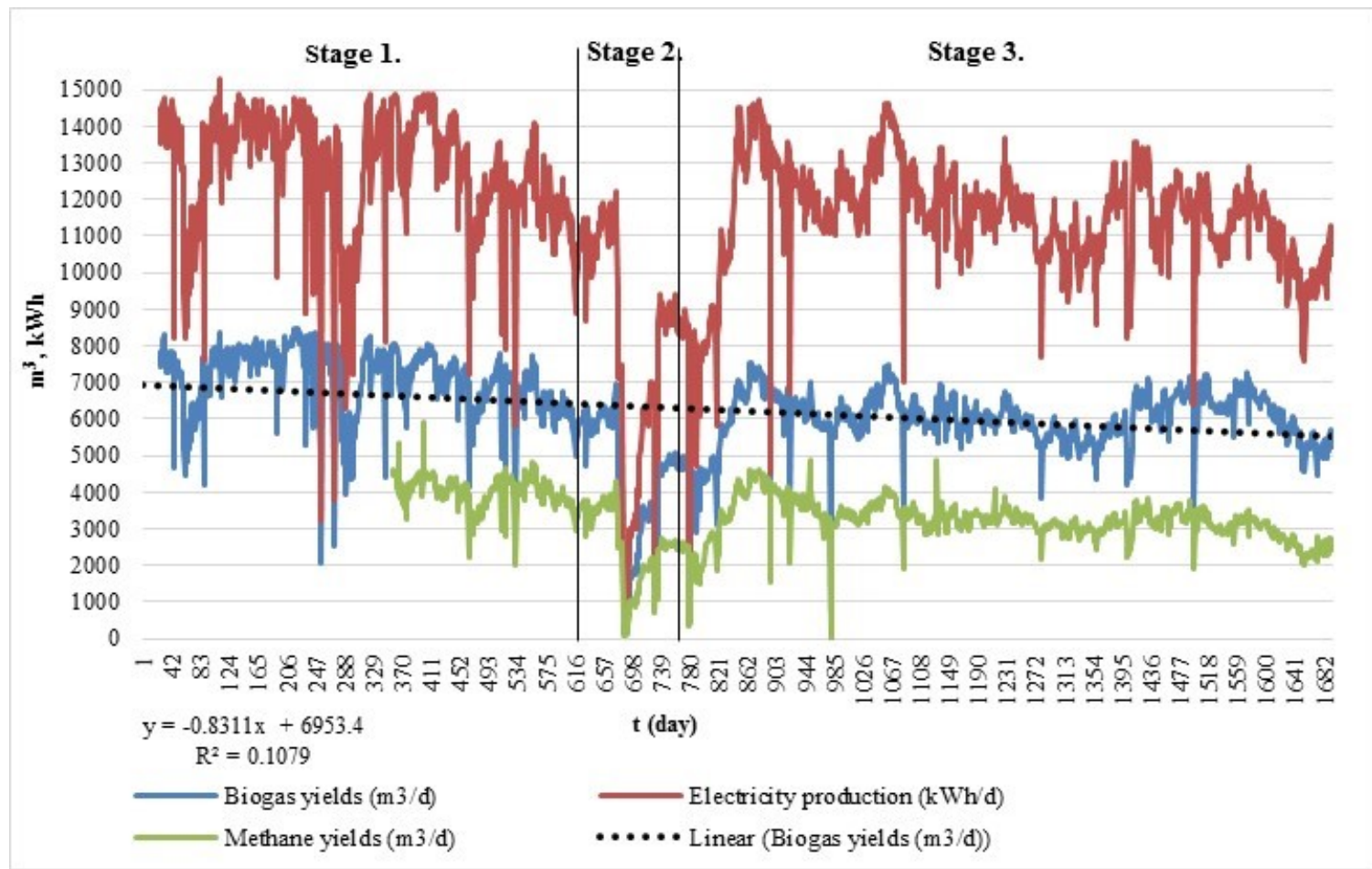

Figure 1. Biogas yields, methane yields, and electricity production in the analyzed biogas plant

During the first phase of operation (1-652. days), 59\% of the daily biogas yields exceeded 7,000 $\mathrm{m}^{3}$ per day, which was basically due to the 1.5-2 times larger amount of annual consumption of corn silage and whey as raw materials. The average daily biogas production in this period was $7,007 \pm 951 \mathrm{~m}^{3}$. The average daily proportion of corn silage and whey fed together was $11 \%$, which is higher than the combined rate of $7 \%$ for the third stage.

In the second phase of the operation of biogas plant (653-793. days), an intense decrease was observed in production. This was due to a malfunction that forced renovation of three fermenters, only limited quantities of raw materials could have been fed and fermented during this six month.

During the third phase (794-1694. days), $94 \%$ of the daily biogas production was less than 7,000 $\mathrm{m}^{3}$ per day, and an average of $6,050 \pm 708 \mathrm{~m}^{3} /$ day biogas was produced. Comparing the raw material consumption to that of the first period, the use of cattle slurry, the extract, and the grass silage increased by $2.5 \%, 1.1 \%$, and $0.4 \%$, respectively, and the use of manure did not change. Accordingly, the proportion of raw materials with higher biogas yield decreased significantly (whey: $-2.4 \%$, corn silage: $-1.6 \%$, pig slurry: $0.1 \%$, dairy sludge: $-0.1 \%$ ). The annual changes of the recipes are shown in Table 3 .

Weiland evaluated German biogas plants in 2004 [29] and 2009[30], and most plants used manure-based mixtures with a range of crops (such as maize, grass, and cereals) as the substrate. Food and vegetable wastes, potato processing residues, whey and fat trap contents were also used as co-substrates with manure. In the 2004 study, manure was the dominant substrate $(75-100 \%$ share) for nearly $50 \%$ of the plants considered. About $83 \%$ of the new German agricultural biogas plants operate with a mixture of crops and manure; $15 \%$ use crops only and just $2 \%$ were operated with manure only. In this study, the biogas plant used in average $82 \%$ of animal slurry and 
manure, $3 \%$ of silo maize and grass silage, $12 \%$ of food industrial wastes, and $2 \%$ of solid separated digestate.

Table 3. The quantitative distribution of raw materials used in the biogas plant

\begin{tabular}{|c|c|c|c|c|c|c|c|c|c|c|}
\hline Years & \multicolumn{2}{|c|}{2012} & \multicolumn{2}{|c|}{2013} & \multicolumn{2}{|c|}{2014} & \multicolumn{2}{|c|}{2015} & \multicolumn{2}{|c|}{2016 Aug. } \\
\hline $\begin{array}{c}\text { Raw } \\
\text { materials } \\
\left(\mathbf{m}^{3}\right)\end{array}$ & $\begin{array}{c}\text { Daily } \\
\text { average } \\
\left(\mathbf{m}^{3}\right)\end{array}$ & $\%$ & $\begin{array}{c}\text { Daily } \\
\text { average } \\
\left(\mathbf{m}^{3}\right)\end{array}$ & $\%$ & $\begin{array}{c}\text { Daily } \\
\text { average } \\
\left(\mathbf{m}^{3}\right)\end{array}$ & $\%$ & $\begin{array}{c}\text { Daily } \\
\text { average } \\
\left(\mathbf{m}^{3}\right)\end{array}$ & $\%$ & $\begin{array}{c}\text { Daily } \\
\text { average } \\
\left(\mathrm{m}^{3}\right)\end{array}$ & $\%$ \\
\hline Cattle slurry & 89.02 & $51 \%$ & 94.14 & $57 \%$ & 103.64 & $56 \%$ & 108.53 & $56 \%$ & 101.52 & $55 \%$ \\
\hline Pig slurry & 46.58 & $27 \%$ & 41.95 & $25 \%$ & 48.33 & $26 \%$ & 52.99 & $27 \%$ & 49.83 & $27 \%$ \\
\hline Silo maize & 5.89 & $3 \%$ & 4.26 & $3 \%$ & 3.1 & $2 \%$ & 2.96 & $2 \%$ & 2.52 & $1 \%$ \\
\hline Grass silage & 1.22 & $1 \%$ & 0.93 & $1 \%$ & 1.92 & $1 \%$ & 2.59 & $1 \%$ & 1.08 & $1 \%$ \\
\hline $\begin{array}{l}\text { Solid } \\
\text { separated } \\
\text { digestate }\end{array}$ & 3.35 & $2 \%$ & 2.21 & $1 \%$ & 3.82 & $2 \%$ & 4.99 & $3 \%$ & 7.22 & $4 \%$ \\
\hline Whey & 16.15 & $9 \%$ & 9.94 & $6 \%$ & 10.09 & $5 \%$ & 10.01 & $5 \%$ & 1002 & $5 \%$ \\
\hline Dairy sludge & 11.88 & $7 \%$ & 10.01 & $6 \%$ & 11.71 & $6 \%$ & 12.14 & $6 \%$ & 13.16 & $7 \%$ \\
\hline $\begin{array}{l}\text { Cattle } \\
\text { manure }\end{array}$ & 0.00 & $0 \%$ & 2.15 & $1 \%$ & 2.43 & $1 \%$ & 0.67 & $0 \%$ & 0.33 & $0 \%$ \\
\hline Summary & 174.09 & $100 \%$ & 165.59 & $100 \%$ & 185.04 & $100 \%$ & 194.88 & $100 \%$ & 185.68 & $100 \%$ \\
\hline
\end{tabular}

\section{Optimization}

The comparative analysis of the optimized and actual recipes examined the composition and the biogas yield of the recipes by varying the quantities of different raw material feeds. The starting value of this changed between $180 \mathrm{~m}^{3}$ (long term constantly enterable quantity) and $210 \mathrm{~m}^{3}$ (maximum fed actual quantity) with $10 \mathrm{~m}^{3}$ stages. The effect of raw materials on the biogas yield - according to the technology - was calculated with a HRT of 25 days.

Our calculations aimed to show that the biogas potential behind the recipes and the significance of the heterosis effect by using LP modelling, compared to the biogas yield of single raw material. The fact, which the body of literature that we know do not contain reliable estimates on the extent of the latter mentioned effect, underlines the significance of this analysis. LP is the most appropriate tool to determine the recipe providing the maximum biogas yield by given recipe ingredients, taking into account the specific unit yields [31].

Since the exact composition of tested individual raw material is unknown and most likely not constant, the calculation used the typical values found in the literature (presented in Table 4.). The biogas yields and the yields of a single feedstock, which can be considered as characteristics, were calculated with means.

The limiting terms of the model were as follows: the specific biogas plant receives daily $100 \mathrm{t}$ cattle slurry, $50 \mathrm{t}$ pig slurry, and 10-10 t whey and dairy sludge, which were rounded to meet the typical daily delivery value. The other three components were the mean values of the collected daily data that increased or reduced with the variance. Another limiting condition was the maximum daily capacity of the fermenter (an average of $180 \mathrm{~m}^{3}$, maximum $210 \mathrm{~m}^{3}$ ). The objective function was to maximize the biogas production. The problem was solved with the use of Solver add-in software of MS Excel. 
Table 4. The quality of different raw materials

\begin{tabular}{|l|c|c|c|c|c|}
\hline \multicolumn{1}{|c|}{ Raw materials } & $\begin{array}{c}\text { Dry } \\
\text { matter } \\
\text { cont. } \\
\mathbf{( D M )} \\
\mathbf{\%}\end{array}$ & $\begin{array}{c}\text { Organic } \\
\text { matter } \\
\text { cont. (OM) } \\
\mathbf{\%}^{*}\end{array}$ & $\begin{array}{c}\text { Biogas yields } \\
\mathbf{m}^{\mathbf{3}} / \mathbf{t} \text { OM }\end{array}$ & $\begin{array}{c}\text { Biogas yields } \mathbf{~ m}^{\mathbf{3} / \mathbf{t}} \\
\text { feedstock }\end{array}$ & $\begin{array}{c}\text { Density } \\
\mathbf{t} / \mathbf{m}^{\mathbf{3}}\end{array}$ \\
\hline Cattle slurry & $3.55^{(2)}$ & $75^{(5)}$ & $200-300^{(1)}$ & 6.66 & 1 \\
\hline Pig slurry & $4^{(1)}$ & $75^{(1)}$ & $300-800^{(3)}$ & 16.50 & 1 \\
\hline Silo maize & $26.09^{(2)}$ & $72^{(4)}$ & $600-700^{(3)}$ & 122.10 & $0.77^{(5)}$ \\
\hline Grass haylage & $24.77^{(2)}$ & $85^{(4)}$ & $560^{(1)}$ & 117.89 & $0.6^{(5)}$ \\
\hline Dairy sludge & $1.98^{(2)}$ & $85^{(4)}$ & $800-950^{(1)}$ & 124.94 & 1 \\
\hline Whey & $3.51^{(2)}$ & $80^{(4)}$ & $500-900^{(3)}$ & 19.63 & 1 \\
\hline Solid separated digestate & $26.02^{(2)}$ & $85^{(4)}$ & $350-780^{(1)}$ & 14.74 & $0.50^{(6)}$ \\
\hline Cattle manure & $21.18^{(2)}$ & $85^{(4)}$ & $600-800^{(3)}$ & 126.02 & $0.75^{(7)}$ \\
\hline
\end{tabular}

(1) [32]

(2) $[33]$

(3) [34]

(4) [32] and [33]

(5) [34] and [33]

(6) $[33]$

(7) [35]

The model - because of its optimizing feature and the consideration of monodigestion biogas yields - did not consider the heterosis effect, the extent of which was calculated by dividing the theoretical (mono-digestion) biogas yield of the actual recipe pasted in the model by the measured yields of the same recipe, after classifying 1,673 pieces of data into quantitative categories and averaging them. The average of the quantitative categories corresponded to the optimized flow rates $(180,190,200$, and 210 $\left.\mathrm{m}^{3}\right)$.

The data have been evaluated and analyzed with the computer programs of MS Excel and SPSS 23 statistical software package. In order to test the normal distribution of the data, one-sample Kolmogorov-Smirnov test and Lilliefors-probe were used. For the simultaneous comparison of the mean values, analysis of variance was used. The significance differences between the winter and summer periods, - with and without Stage 2 phase - were analyzed by one-way analysis of variance (ANOVA) using Tukey b and Duncan tests at $\mathrm{P}>0.05$ significant level. Factor analysis, - based on Kaiser-MeyerOlkin Measure of Sampling Adequacy probe (0.616) and Bartlett's test - was applied to analyze different components under linear relationship, and to reduce the number of studied components. The relationship between the main raw materials and the biogas production was detected by a linear regression analysis. In the linear regression model, biogas yields without Stage 2 phase were considered as Y (i.e. dependent factor).

\section{Results and Discussion}

Technology and operational parameters of the studied biogas plant 
This interval indicates the degradability of the given raw material, and the time needed for gas production to be commenced. The following are the main operational parameters of the studied agricultural biogas plant:

- Temperature: $32.0^{\circ} \mathrm{C}$

- Capacity (V): $179.8 \mathrm{~m}^{3} / \mathrm{d}$

- Reactor value (Vr): $4,500 \mathrm{~m}^{3}$

- Hydraulic retention time (HRT) (Gruber, 2006): $25.0 \mathrm{~d}\left(\mathrm{Vr} \mathrm{m}^{3} / \mathrm{Input}^{3 *} \mathrm{~d}\right.$ )

- Biogas quantity: $5,988.3 \mathrm{Nm}^{3} / \mathrm{d}$

- Biogas quantity: 2,052,000 Nm³/a

- Amount of oTS: 0.71 Input t oTS/d

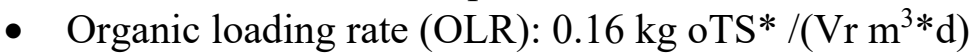

- Dry matter load: $0.24 \mathrm{~kg}$ TS (dry matter content)/ $\left(\mathrm{Vr} \mathrm{m}^{3 * \mathrm{~d})}\right.$

- Methane concentration in biogas: $55.2 \%$

- Biogas productivity: $1.32 \mathrm{Nm}^{3} /\left(\mathrm{Vr} \mathrm{m}^{3 *} \mathrm{~d}\right)$

- Specific biogas production: $33.3 \mathrm{Nm}^{3} /\left(\right.$ Input $\left.\mathrm{m}^{3 *} \mathrm{~d}\right)$

- Specific biogas yield: $8.39 \mathrm{Nm}^{3} /\left(\mathrm{kgVs}^{*} \mathrm{~d}\right)$

- Electricity production: 4,214,620 kWh/a

- Electricity production: $11,305.7 \mathrm{kWh} / \mathrm{d}$

In case of the organic load, our results were lower $\left(0.16 \mathrm{~kg}\right.$ oTS $\left./ \mathrm{Vr} \mathrm{m}{ }^{3} * \mathrm{~d}\right)$ than the average ORT in Braun et al. (2006) [23]. It's proven to be effective for the biogas productivity in the studied biogas plant, compared to Braun et al. (2006) [23] results. However, the average methane content of biogas was lower within the studied period (2012-2016).

The hydraulic retention time (HRT) had been established as 25 days based on Gruber (2006) [19] study, which is lower than the optimal value based on other publications. The Biogas Handbook suggested a minimum retention time of 30 to 40 days under mesophilic conditions. Mendaro et al. (2011) [24] analyzed four digestate samples in batch reactors. The methane yield was shown to be highly influenced by OLR and by feedstock quality of the biogas plant, but the HRT only showed limited effects.

\section{Optimization of raw material composition}

Descriptive statistic of biogas yields in summer and winter is shown in Table 5. Distribution of the biogas yields in summer and winter periods was normal based on OneSample Kolmogorov-Smirnov test.

Table 5. Descriptive statistic of biogas yields in winter and summer periods

\begin{tabular}{|c|c|c|c|c|c|c|c|c|}
\hline \multirow{2}{*}{$\begin{array}{c}\text { Biogas } \\
\text { yields } \\
\left(\mathrm{m}^{3} / \mathrm{d}\right)\end{array}$} & \multirow{2}{*}{$\mathbf{N}$} & \multirow{2}{*}{ Mean } & \multirow{2}{*}{$\begin{array}{c}\text { Std. } \\
\text { Deviation }\end{array}$} & \multirow{2}{*}{$\begin{array}{l}\text { Std. } \\
\text { Error }\end{array}$} & \multicolumn{2}{|c|}{$\begin{array}{l}95 \% \text { Confidence } \\
\text { Interval for Mean }\end{array}$} & \multirow{2}{*}{ Minimum } & \multirow{2}{*}{ Maximum } \\
\hline & & & & & $\begin{array}{l}\text { Lower } \\
\text { Bound }\end{array}$ & $\begin{array}{l}\text { Upper } \\
\text { Bound }\end{array}$ & & \\
\hline $\begin{array}{l}\text { Winter } \\
\text { period }\end{array}$ & 1528 & 6442.75 & 942.53 & 24.11 & 6395.45 & 6490.04 & 56.96 & 8481.00 \\
\hline $\begin{array}{l}\text { Summer } \\
\text { period }\end{array}$ & 877 & 6427.73 & 964.78 & 32.58 & 6363.78 & 6491.66 & 56.96 & 8481.00 \\
\hline Total & 2405 & 6437.27 & 950.53 & 19.38 & 6399.26 & 6475.28 & 56.96 & 8481.00 \\
\hline
\end{tabular}


Based on Levene-test, the variance of data was homogeneous. No significance differences were detected at $\mathrm{P}>0.05$ significant level by ANOVA analysis for the biogas yields between the winter and summer periods, because the significance level of F-probe was 0.709 . In case of the fed amount (oTS $(\mathrm{kg} / \mathrm{d})$ ), no significance differences $($ Sig. $0.6<$ ) was detectable between the winter and summer periods, therefore permanent and stable quality of feedstock and OLR was found in the studied agricultural biogas plant. The daily fed amount of total animal slurry and manure, silo maize, grass silage, and milk industrial wastes $\left(\mathrm{m}^{3}\right)$ differed significantly in the summer and winter periods, which was based on variance analysis (Sig. 0.00). In case of solid separated digestate (Sig. 0.494) the fed amounts were similar in all seasons.

The Stage 2 data series were excluded from the database, because it was identified as a technical error. Factor analysis and linear regression analysis were performed and then applied. Distribution of quantity of used raw materials was normal based on the Kolmogorov-Smirnov test.

Factor analysis based on the Kaiser-Meyer-Olkin Measure of Sampling Adequacy probe (0.616) and the Bartlett's Test was well applicable. Based on principal Component Analysis and Rotated Component Matrix, the biogas yields, quantity of silo maize, solid digestate, and total slurry and manure $\left(\mathrm{m}^{3} / \mathrm{d}\right)$ could be separated in the first group. These components were determined as the biogas yield factors. The second group were classified as the acidity factors like amount of oTS $(\mathrm{kg} / \mathrm{d})$ and $\mathrm{pH}$. Milk industrial wastes $\left(\mathrm{m}^{3} / \mathrm{d}\right)$ were classified as a third group. The most important factor was the silo maize, which showed a strong linear correlation with the biogas yield. An inversely proportional relationship could be detected between the biogas yield and the quantity of solid digestate, slurry, and manure. The more slurry, manure, and digestate used in the biogas plant as raw material, there was less biogas production, and therefore decreased effectiveness of the plant. Higher ratio of organic matter content in the fed raw materials often cased lower $\mathrm{pH}$, therefore increased the acidity in the digester. Factor analysis of feedstock, biogas yield, oTS, OLR and $\mathrm{pH}$ are detailed below:

\section{Components}

1. Biogas yield factor:

- Silo maize $\left(\mathrm{m}^{3} / \mathrm{d}\right)(-0.757)$

- Solid digestate $\left(\mathrm{m}^{3} / \mathrm{d}\right)(0.671)$

- Biogas yields $\left(\mathrm{m}^{3} / \mathrm{d}\right)(-0.650)$

- Total slurry and manure $\left(\mathrm{m}^{3} / \mathrm{d}\right)(0.609)$

2. Acidity factor:

- Amount of oTS $(\mathrm{kg} / \mathrm{d})(0.803)$

- $\mathrm{pH}(-0.675)$

3. Milk industrial wastes $\left(\mathrm{m}^{3} / \mathrm{d}\right)(0.862)$

Based on the regression analysis of biogas yields $\left(\mathrm{m}^{3} / \mathrm{d}\right)$ and silo maize $\left(\mathrm{m}^{3} / \mathrm{d}\right)$, we can build up a linear regression equation with low dependability $\left(\mathrm{R}=0.38 ; \mathrm{R}^{2}=0.145\right)$. Weak correlation was observed between the biogas yields and total amount of slurry and manure $\left(\mathrm{m}^{3} / \mathrm{d}\right)$ with linear regression analysis $\left(\mathrm{R}=0.371, \mathrm{R}^{2}=0.137\right)$ at $\mathrm{P}>0.05$ significant 
level. In case of applied solid digestate the dependency was also week $\left(R=0.217, R^{2}=\right.$ 0.047).

An average difference of 2.1 times was observed between the model and the measured values by a relative low standard deviation $(\mathrm{R}=0.40)$, however, with very different extreme values (minimum of 0.02 to a maximum of 3.07 ).

Taking into account the daily accurately measured values, the objectivity of the LP model, and the model considering only the individual (mono-digestion) biogas yield of the single raw materials, we believe that the heterosis effect in this recipe could result in a $110 \%$ excess yield. However, this value is only the best possible approximation, since the actual composition of raw materials used in the given biogas plant - thus their biogas yields - is not precisely known, and it may not correspond to the used average values. Considering the average standard deviation, it can be stated that the heterosis effect results in a 1.7-2.5-fold yield increase under the test conditions.

Although the amount of corn silage, grass silage and the extract - as variables was minimal in the recipe, they played a crucial role in the total biogas yield of the recipe because of their significantly higher organic matter content and specific biogas yield (Figure 2.).

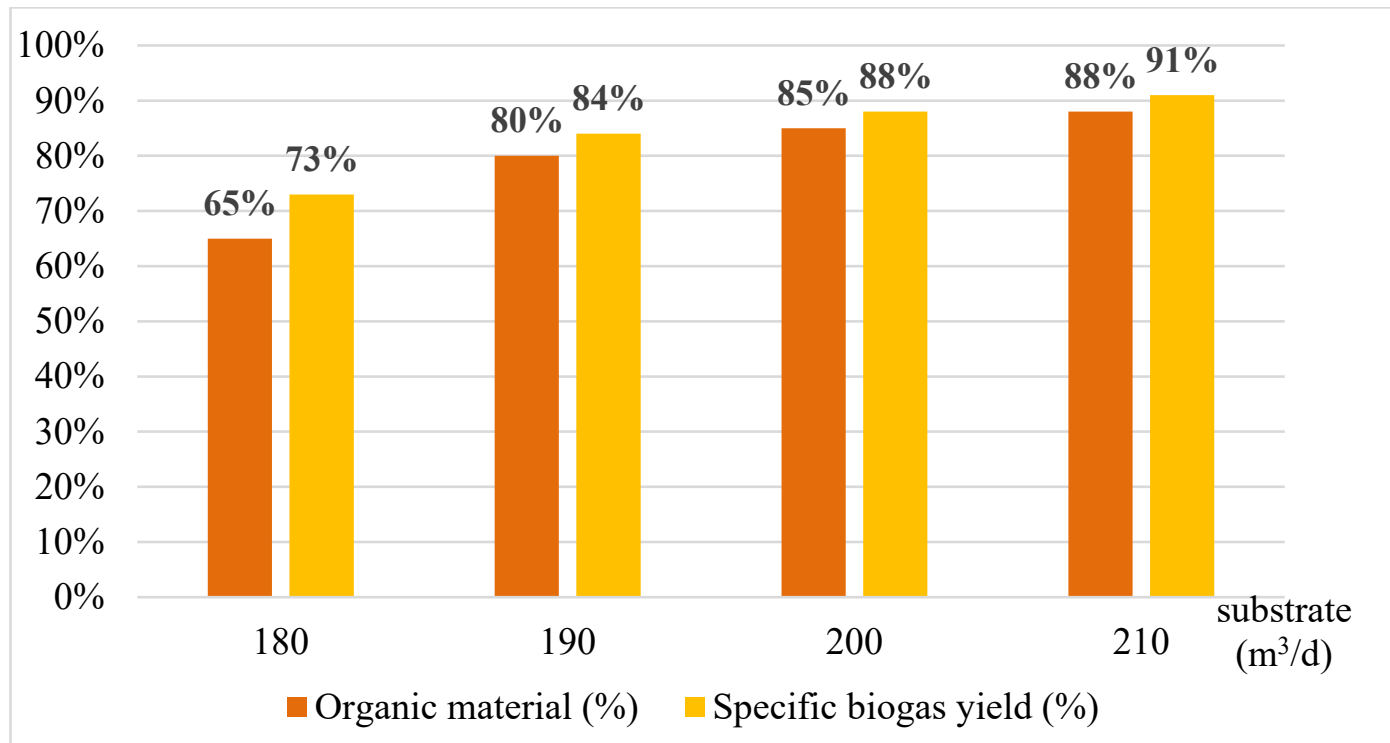

Figure 2. The correlation between organic material content and specific biogas yield

The recipe composition and the actual daily biogas yields based on the operational measures are detailed in the upper part of Table 6 , while the same parameters as results of the optimization are shown in the lower part of the table. The biogas yield of the model at $180 \mathrm{~m}^{3}$ daily input level was $16 \%$ lower, while at higher input levels it was $18-66 \%$ higher than the average of the yields measured in the plant. 
Table 6. The real (measured) and the optimized values regarding the recipe

\begin{tabular}{|c|c|c|c|c|c|c|c|c|c|}
\hline $\begin{array}{c}\text { Daily } \\
\text { feedstock } \\
\left(\mathbf{m}^{\mathbf{3}}\right)\end{array}$ & $\begin{array}{c}\text { Cattle } \\
\text { slurry }\end{array}$ & $\begin{array}{c}\text { Pig } \\
\text { slurry }\end{array}$ & $\begin{array}{c}\text { Silage } \\
\text { maize }\end{array}$ & $\begin{array}{c}\text { Grass } \\
\text { silage }\end{array}$ & $\begin{array}{c}\text { Solid } \\
\text { separate } \\
\text { digestate }\end{array}$ & Whey & $\begin{array}{c}\text { Dairy } \\
\text { sludge }\end{array}$ & $\begin{array}{c}\text { Cattle } \\
\text { manure }\end{array}$ & $\begin{array}{c}\text { Biogas } \\
\text { yield } \\
\left(\mathbf{m}^{\mathbf{3}}\right)\end{array}$ \\
\hline \multicolumn{8}{|c|}{ Real values, measured in the biogas plant } \\
\hline $175-185$ & 98.9 & 48.6 & 7.2 & 2.3 & 9.6 & 11.2 & 10.8 & 0.8 & 6496 \\
\hline $185-195$ & 106.2 & 50.9 & 5.5 & 3.8 & 9.5 & 10.3 & 11.9 & 1.1 & 6193 \\
\hline $195-205$ & 112.5 & 52.5 & 4.5 & 5 & 9.5 & 10.5 & 12.2 & 2.1 & 6110 \\
\hline $205-215$ & 115.1 & 56 & 4.5 & 4.9 & 8.9 & 10.3 & 14.3 & 2.6 & 6042 \\
\hline \multicolumn{8}{|c|}{ Results and values by the optimization } \\
\hline 180 & 100 & 50 & 2.9 & 0.2 & 3 & 10 & 10 & 0 & 5425 \\
\hline 190 & 100 & 50 & 9.1 & 1.4 & 3 & 10 & 10 & 0 & 7308 \\
\hline 200 & 100 & 50 & 9.1 & 5.1 & 4.9 & 10 & 10 & 0 & 8731 \\
\hline 210 & 100 & 50 & 9.1 & 5.1 & 9.9 & 10 & 10 & 0 & 10046 \\
\hline
\end{tabular}

In case of the $180 \mathrm{~m}^{3}$ per day input level, the actual recipe contained a significantly smaller proportion of the substrate with the lower biogas yield compared with the optimized $180 \mathrm{~m}^{3}$ per day capacity. Consequently corn silage, grass silage, and digestate were present in a 3.15 -fold proportion (19\% compared to $6 \%$ ), so the difference of the proportion of valuable substrates was much higher than of biogas yields (6496 $\mathrm{m}^{3}$ per day compared to $5425 \mathrm{~m}^{3}$ per day).

Assuming that the raw material in the plant had more favorable parameters (like organic matter content and biogas yield) than the average, the degree of the heterosis effect was corrected upwards with the standard deviation (to 2.50). The measured and the optimized daily yield was practically identical $\left(6496 \mathrm{~m}^{3}\right.$ or $\left.6445 \mathrm{~m}^{3}\right)$, despite the divergence of the more valuable components.

The considerable surplus yield (18-66\%) of the optimized recipe in case of the 190 to $210 \mathrm{~m}^{3}$ per day input volume was due to the decreased proportion of ingredients with high biogas yield in the higher input volume under the actual operating conditions and the increase of their proportion in the model. The most recommended of these was the feeding of corn silage; the LP model increased first the volume of this ingredient to the maximum level (in addition to leaving the other two substrates on minimum level), than the volume of grass silage and finally the volume of extract. Our calculations suggested that the maximum limit could be reached at $213 \mathrm{~m}^{3}$ daily input volume. If there was no limits for the variables, the model would have recommended the solely feeding of corn silage - in addition to a minimal feeding of grass silage and extract - at $210 \mathrm{~m}^{3}$ daily input level with an estimated biogas yield of $12,637 \mathrm{Nm}^{3} /$ day, which is more than double of the relevant operating data.

Against this background, we believe that a significant excess yield could be achieved with the use of our model compared to the actual measured data.

It is important to point out, that even a relatively small over-sizing of the fermenter capacity could result in a significant yield increase. In this case study, a 5.5\% increase of the input volume (from 180 to $190 \mathrm{~m}^{3}$ ) resulted in a $35 \%$ increase of the biogas yield when using optimized recipe. However, the increasing rate of the yield according to the law of diminishing returns - decreased significantly in case of further similar capacity increases. In turn, the actual operating data displayed the opposite 
tendency, which is probably due to the fact that after recovering the breakdown in livestock farms, the operators tried to dispose the most possible volume of the accumulated slurry in the biogas plant, resulting in a higher proportion of slurry in the greater input volume. However, large-scale or long-term decline in livestock can be a serious threat not only for the security of the raw material basis, but for the utilization of unmarketable by-products of the biogas production (primarily waste heat).

\section{CONCLUSIONS}

Biogas plants serving for disposal of the slurry from livestock farms have relatively modest possibilities for increasing yield, since they are scaled for constantly processing hardly storable raw materials with modest biogas yields (a variety of slurry and food processing by-products). Optimization of this kind of feedstocks is possible, but combines with significant limitations. Because these feedstocks make up the vast majority of the recipe, the seasonality is much less important compared to other types of biogas plants. However, substrates with the high organic content (silage maize, grass silage, solid separate digestate) are responsible for most of the biogas production, so they should be considered when scaling up the fermenter.

A temporary or permanent, minor decrease in the feedstock from the livestock can make the recipe use a higher proportion of energy crops, resulting in a significant increase in the biogas production. Energy crops also have the land demand, but it's significant smaller than the crop production for feeding.

\section{ACKNOWLEDGMENTS}

This study and our research work were partly supported by the University of Debrecen, Faculty of Economics and Business Research Fund (in Hungarian: GTK Kutatási Alap).

\section{CONFLICTS OF INTEREST}

The authors declare that there is no conflict of interests regarding the publication of this paper.

\section{REFERENCES}

[1] Popp, J., Lakner, Z., Harangi-Rákos, M., and Fári, M. (2014). The effect of bioenergy expansion: food, energy, and environment. Renewable and Sustainable Energy Reviews, 32, 559-578.

[2] Popp, J., Harangi-Rákos, M., Petô, K., and Nagy, A. (2013). Bioenergy: Risks to food-, energy-and environmental Security. APSTRACT: Applied Studies in Agribusiness and Commerce(4/5), 121-130.

[3] Fuchsz, M., and Kohlheb, N. (2015). Comparison of the environmental effects of manure-and crop-based agricultural biogas plants using life cycle analysis. Journal of Cleaner Production, 86, 60-66.

[4] Fogarassy, C., and Nábrádi, A. (2015). Proposals for low-carbon agriculture production strategies between 2020 and 2030 in Hungary. APSTRACT: Applied Studies in Agribusiness and Commerce, 9(4).

[5] für Umwelt, B. L. (2007). Biogashandbuch Bayern, Materialienband. Augsburg, Germany, 13-14. 
[6] Chen, Y., Cheng, J. J., and Creamer, K. S. (2008). Inhibition of anaerobic digestion process: a review. Bioresource Technology, 99(10), 4044-4064.

[7] Hartmann, H., and Ahring, B. K. (2005). Anaerobic digestion of the organic fraction of municipal solid waste: influence of co-digestion with manure. Water research, 39(8), 1543-1552.

[8] Linke, B., Muha, I., Wittum, G., and Plogsties, V. (2013). Mesophilic anaerobic co-digestion of cow manure and biogas crops in full scale German biogas plants: a model for calculating the effect of hydraulic retention time and VS crop proportion in the mixture on methane yield from digester and from digestate storage at different temperatures. Bioresource Technology, 130, 689-695.

[9] Ward, A. J., Hobbs, P. J., Holliman, P. J., and Jones, D. L. (2008). Optimisation of the anaerobic digestion of agricultural resources. Bioresource Technology, 99(17), 7928-7940.

[10] Amon, T., Amon, B., Kryvoruchko, V., Machmüller, A., Hopfner-Sixt, K., Bodiroza, V., Hrbek, R., Friedel, J., Pötsch, E., and Wagentristl, H. (2007). Methane production through anaerobic digestion of various energy crops grown in sustainable crop rotations. Bioresource Technology, 98(17), 3204-3212.

[11] Amon, T., Amon, B., Kryvoruchko, V., Zollitsch, W., Mayer, K., and Gruber, L. (2007). Biogas production from maize and dairy cattle manure-influence of biomass composition on the methane yield. Agriculture, Ecosystems \& Environment, 118(1), 173-182.

[12] Nielsen, L. H., Hjort-Gregersen, K., Thygesen, P., and Christensen, J. Samfundsøkonomiske analyser af biogasfællesanlæg. In: Proc., DAKOFAkonference om organisk affald.

[13] Møller, H. B., Sommer, S. G., and Ahring, B. K. (2004). Biological degradation and greenhouse gas emissions during pre-storage of liquid animal manure. Journal of Environmental Quality, 33(1), 27-36.

[14] Wu, X., Yao, W., Zhu, J., and Miller, C. (2010). Biogas and CH 4 productivity by co-digesting swine manure with three crop residues as an external carbon source. Bioresource Technology, 101(11), 4042-4047.

[15] Cuetos, M. J., Gómez, X., Otero, M., and Morán, A. (2008). Anaerobic digestion of solid slaughterhouse waste (SHW) at laboratory scale: influence of codigestion with the organic fraction of municipal solid waste (OFMSW). Biochemical Engineering Journal, 40(1), 99-106.

[16] Cavinato, C., Fatone, F., Bolzonella, D., and Pavan, P. (2010). Thermophilic anaerobic co-digestion of cattle manure with agro-wastes and energy crops: comparison of pilot and full scale experiences. Bioresource Technology, 101(2), 545-550.

[17] Bouallagui, H., Cheikh, R. B., Marouani, L., and Hamdi, M. (2003). Mesophilic biogas production from fruit and vegetable waste in a tubular digester. Bioresource Technology, 86(1), 85-89.

[18] Hernández-Berriel, M. C., Márquez-Benavides, L., González-Pérez, D., and Buenrostro-Delgado, O. (2008). The effect of moisture regimes on the anaerobic degradation of municipal solid waste from Metepec (Mexico). Waste Management, 28, S14-S20.

[19] Gruber, W. (2007). Biogasanlagen in der Landwirtschaft. Verbraucherschultz, Ernährung, Landwirtschaft, 1453.

[20] Group, B. T. (2003). BTG Anaerobic Digestion. 
[21] Jenagi, I. (2002). Production methane gas from effluent. Adelaide University, Diploma Individual Project.

[22] Kaosol, T., and Sohgrathok, N. (2012). Influence of Hydraulic Retention Time on Biogas Production from Frozen Seafood Wastewater Using Decanter Cake as Anaerobic Co-digestion Material. TVS, 20, 0.20.

[23] Braun, R., Madlener, R., and Laaber, M. Efficiency evaluation of energy crop digestion plants. In: Proc., Proceedings of the 7th FAO/SREN Workshop" The Future of Biogas for Sustainable Energy Production in Europe.

[24] Menardo, S., Gioelli, F., and Balsari, P. (2011). The methane yield of digestate: effect of organic loading rate, hydraulic retention time, and plant feeding.

Bioresource Technology, 102(3), 2348-2351.

[25] Schievano, A., Pognani, M., D’Imporzano, G., and Adani, F. (2008). Predicting anaerobic biogasification potential of ingestates and digestates of a full-scale biogas plant using chemical and biological parameters. Bioresource Technology, 99(17), 8112-8117.

[26] Lindorfer, H., Lopez, C. P., Resch, C., Braun, R., and Kirchmayr, R. (2007). The impact of increasing energy crop addition on process performance and residual methane potential in anaerobic digestion. Water science and technology, 56(10), 55-63.

[27] Pullammanappallil, P., Svoronos, S., Chynoweth, D., and Lyberatos, G. (1998). Expert system for control of anaerobic digesters. Biotechnology and Bioengineering, 58(1), 13-22.

[28] Preissler, D., Drochner, U., Lemmer, A., Oechsner, H., and Jungbluth, T. (2010). Sulphur binding in biogas plants using ferric salts. Landtechnik, 65(3), 201-203.

[29] Weiland, P. (2004). Erfahrungen deutscher Biogasanlagen-Ergebnisse einer bundesweiten Bewertung. Institut für Technologie und Biosystemtechnik, Bundesforschungsanstalt für Landwirtschaft (FAL).

[30] Biosystemtechnik, I. f. A. u., and Rohstoffe, F. N. (2009). Biogas-Messprogramm 2: 61 Biogasanlagen im Vergleich, Fachagentur Nachwachsende Rohstoffe.

[31] Arora, J. S. (2004). Introduction to optimum design, Elsevier Academic Press, The University of Iowa.

[32] Al Seadi, T. (2001). Good practice in quality management of AD residues from biogas production.

[33] Mézes, L. (2011). Mezőgazdasági és élelmiszeripari biogáz-termelés optimalizálása. University of Debrecen, Debrecen, Hungary

[34] Eder, B., Krieg, A., and Schulz, H. (2006). Biogas-Praxis: Grundlagen, Planung, Anlagenbau, Beispiele, Wirtschaftlichkeit, Ökobuch-Verlag.

[35] Chadwick, D. (2005). Emissions of ammonia, nitrous oxide and methane from cattle manure heaps: effect of compaction and covering. Atmospheric environment, 39(4), 787-799.

Article copyright: (C) 2017 Lili Mézes, Attila Bai, Dávid Nagy, István Cinka, and Zoltán Gabnai. This is an open access article distributed under the terms of the Creative Commons Attribution 4.0 International License, which permits unrestricted use and distribution provided the original author and source are credited. 